MUDRA: Journal of Finance and Accounting, Volume 4, Issue 2, July-December 2017, pp. 145-166 doi: 10.17492/mudra.v4i02.11452

\title{
Market Value and Capital Structure: A Study of Indian Manufacturing Firms
}

\author{
Dhananjaya $K .^{*}$
}

\begin{abstract}
India witnessed significant development in stock market in the post 1990s due to series of reform measures. As result, firms are able to raise market based capital which helped them to reduce their dependence on institution based finance. Consequently, market valuation of the firm has become an important variable in corporate finance decisions. However, traditional theories of capital structure fail to offer unambiguous explanation on the impact of market value on capital structure. To bridge this lacuna in capital structure literature, Baker and Wrugler (2002) propounded market timing theory which argues that firms' time the market, that is, firms raise equity capital when market valuation is high and buy back when market valuation is lower and hence the current capital structure of the firm is the cumulative result of past attempts to time the equity market. In this study we attempt to understand the role of market value in influencing the capital structure decisions of the manufacturing firms in India. We find that market value negatively influences the debt ratio both in short term and long term indicating the practice of market timing. Further, we find that negative impact does indeed come from changes in equity issues rather than changes in retained earnings or debt retirement.
\end{abstract}

Keywords: Capital structure; Market valuation; Market timing.

\subsection{Introduction}

Over the last two decades stock market in India has witnessed tremendous growth due to the series of capital market reforms initiated in the early 1990s. As a result, stock market has emerged as an important alternative source of finance for corporate which helped to diffuse excessive burden on banking system (RBI, 2015).

*Doctoral scholar, Institute for Social and Economic Change, Bengaluru, Karnataka, India. (Emailid: dhananjayak@isec.ac.in) 
Traditional theories seem to have overlooked the role of stock market in influencing firms' capital structure. For instance, in the irrelevance theory of Modigliani \& Miller (1958), there is no gain from shifting between debt and equity as in efficient capital markets costs of these sources of finance do not change independently. Trade off theory argues that the capital structure is primarily determined by the cost and benefits of debt financing, hence, temporal fluctuations in the market value of the firm should have only temporary or short term effect on capital structure. Similarly, agency theory maintains that debt financing involves agency cost and tax benefits and optimum capital structure balances these two elements of debt financing. On the other hand, pecking order hypothesis states that information asymmetry in the capital market determines the source of finance for the firm. Firm facing least information asymmetry problem would be dependent more on external finance and internal capital would be the major source of finance for firms facing information asymmetry. However, as argued by, Demirguc-Kunt \& Maksmovic (1996), optimum capital structure may not be possible in the absence of well-functioning equity market which implies that stock market is an important determinant of capital structure. Yet, they argue that the impact of stock market on capital structure of the firm is not unambiguous. Sudden access to well-developed stock market may result in substitution of outside equity for outside debt in the case of firms that are previously constrained to issue only outside debt resulting in decrease in firms' debt equity ratio; substitute outside equity for inside equity in which case debt equity ratio will not be affected; or firms may find expansion more attractive as well functioning stock market enhances entrepreneur's ability to diversify risks and impact of this on debt-equity ratio depends on how the expansion is financed. In this connection, Baker \& Wurgler (2002) expounded market timing hypothesis which argues that a firms' capital structure is the result of past market timing. Firms issue more equity when market value is high and buy back when they experience low market value. Hence, market timing theory establishes direct connection between firms' market value and its capital structure decisions. With this background, the paper attempts to empirically examine the impact of firms' market value on the capital structure decisions in Indian manufacturing firms.

The remainder of the paper is structured as follows. In section 2, we briefly review the theoretical and empirical literature on capital structure decisions. In section 3, we discuss composition of the capital structure of sample firms. Section 4 focuses on source of data and methodology used in the paper. Section 5 presents the results of the analysis and findings, and in section 6 contains conclusion. 


\subsection{Determinants of Capital Structure: Theory and Evidence}

Modigliani-Miller irrelevance theorem kick started the debate on the issue of capital structure. Modigliani \& Miller (1958) claimed that the value of the firm depends on the marginal productivity and cost of the capital and source of capital is irrelevant to the value of the firm which came to be known as Modigliani and Miller irrelevance theorem. According to Modigliani \& Miller (1958) in a world of perfect capital market and no tax, firms' investment depends on the return on investment and cost of capital. Investment opportunity will be pursued if and only if the return on investment is equal or more than marginal cost of capital. This implies that marginal cost capital is the cut off point for the investment and the kind of instruments used to finance the investment is irrelevant. However, unrealistic assumptions of perfect capital market, no taxes and no bankruptcy costs of debt financing of Modigliani \& Miller (1958) irrelevance theorem came under severe criticisms. In response to this, Modigliani \& Miller (1963) acknowledged the tax benefits involved in debt financing. They maintained that firms' value would be influenced by the benefits conferred by the debt financing through the tax deductibility of the interest payments. Due to this, firms may be motivated to rely completely on debt financing as it provides tax shield. But Miller (1977) pointed out that tax advantage conferred by debt financing would be offset by the disadvantages of personal tax, and hence irrelevance theorem would hold good even in the presence of tax. Further, Miller (1977) presumed that debt financing does not have any bankruptcy costs and hence riskless. Therefore, according to Modigliani \& Miller (1963) there is motivation for higher leverage due to the tax advantage and absence of bankruptcy costs of debt financing. However, Baxter (1967) recognized the bankruptcy cost of debt financing. He pointed out that high leverage would increase the bankruptcy costs emanating from the probability of default. This would increase the riskiness of the earning and consequent cost of capital to the firm. Jensen \& Mackling (1976) argued that debt financing also involves agency cost. According to them, financing through debt capital will motivate shareholders (agents) to invest in risky projects. If the project generates high return, shareholders will take away most of this return, and if it fails creditors will have to bear the cost as shareholders have limited liability.

Based on the tax benefit and bankruptcy cost of debt financing, DeAngelo \& Masulis (1980) developed static trade off theory, wherein the tax benefits offered by debt financing is offset by increased bankruptcy costs of debt financing. Trade- off theory proposes that the firm will have a target capital structure which balances between the benefits and costs associated with the debt financing. However, Hovakimian et al, (2001) expounded dynamic trade off theory wherein they argued that the optimum target capital 
structure is not static. It deviates as firms' conditions change from time to time. Jalal (2007) claims that actual leverage ratio varies around the target within an acceptable range as a response to the changes in the firm conditions.

On other hand, Myers (1984) proposed pecking order theory which argues that, due to the problem of information asymmetry in capital market, firms follow pecking order in their financing decisions. According to Myers \& Majluf (1984) inside managers possess more information about the true value of the firm than outside managers. Because of this outside investors face adverse selection problem in their investment decisions. This may result in mispricing of the equity by the market leading to higher cost of capital. They argue that the problem of information asymmetry and resultant friction in the capital market is more in equity market as compared to debt market leading to varying cost of capital for the firm. In response to this problem, firms will follow pecking order in their financing decisions, that is, they would prefer to finance all their projects through internal capital, if possible, and if sufficient internal capital is not available they will prefer debt capital to equity capital. Hence, equity capital is the least preferred capital in the presence of information asymmetry in the capital market. The theory clearly implies that the underdevelopment of the capital market will seriously limit the financing options available to the firms which will adversely affect corporate investment. Conversely, it argues that as capital market develops the problem information asymmetry and resulting adverse selection problem reduces and firms will be able to finance their projects from capital market.

However, none of the above theories unambiguously explains the role of market value of the firm in capital structure decisions. For instance, though modified version of trade off theory recognises importance of market value in capital structure decisions, it argues that market value results in only short term deviation from target capital and these deviations quickly reverse to target capital structure (Alti, 2006). On other hand, market value reflects the growth opportunities of the firm under pecking order hypothesis. However, Myres \& Majluf (1984) argues that firm with growth opportunities will not issue the equity immediately and will wait till information asymmetry reduces in order to avoid issuing at an average and unfavourable price that reflects the fact that lower quality firms also issue. Due to this, firms may have to find interim source of finance until they can issue equity. Therefore, market value may actually increase the debt capacity of the firm as adverse selection problem is less in the case debt financing than equity. Secondly, firms may not issue equity even if they experience higher market value, if there is no need for immediate proceeds. Hence, the impact of market value on capital structure is not unambiguous under pecking order hypothesis. More convincing and unambiguous explanation to the role of market value in capital structure decision has 
been provided by Baker \& Wurgler (2002) who proposed market timing theory that directly links stock market and capital structure. According to them, equity market timing denotes the practice of raising equity capital at high price and repurchasing shares at low price with the objective to exploit the fluctuations in the cost of equity capital. Baker \& Wurgler (2002) argue that firms are likely to issue equity rather than debt when the market value is high and tend to repurchase equity when market value is low. Hence, market timing theory argues that the current capital structure of the firm is the result of past attempts to time the market depending on the market value of the firm. The theory also implies that the financing decision is influenced by the conditions in the stock market. Baker \& Wurgler (2002) documented strong negative relationship between past market valuations, measured by market to book value, and leverage ratio. Whereas, trade-off theory argues that temporary fluctuations in market to book value will have temporary effects, Baker \& Wurgler (2002) showed that market to book value will have long term impact on the capital structure of the firm. They further demonstrated that market timing leads to permanent change in the cash balance of the firms, which indicates that firms issue equity when market value is high even if there is no need for proceeds. Therefore, according to Baker \& Wurgler (2002), the natural explanation for the negative and persistent effect of market value on capital structure is market timing, i.e., firms issue equity when market value is high and buy back when market value is lower.

Diverse theoretical arguments also led to extensive empirical research on the determinants of capital structure. Most of the studies focused on firm specific determinants of capital structure such as asset tangibility, size, financial distress costs, profitability, growth rate, tax rates, non-debt tax shields, interest coverage, liquidity etc. (Harris \& Raviv, 1991, Fama \& French, 2002, Frank \& Goyal, 2003, Frank \& Goyal, 2009, Ali Ahmed \& Hisham, 2009, Tong \& Green, 2005 and Daskalakis \& Psillaki, 2008 among others).

Few studies also examined the link between stock market and corporate structure. For instance, in a cross country study, Demirguc-Kunt \& Maksmovic (1996) examined the role of stock market development on debt-equity ratio at aggregate level. Using an index of stock market development consisting of stock market size, and liquidity, they found that during the initial stage of stock market development debtequity ratio increases as both debt and equity capital increases. However, as stock market develops further, equity capital substitutes debt capital resulting in lower debt equity ratio. Following market timing theory of Baker \& Wurgler (2002), few studies also examined the role market value of the firm on debt equity ratio. For example Chen \& Zhao (2006) detected inverse relationship between market to book ratio and debt equity 
ratio which indicates that stock market development will increase equity capital. Similarly, Rajan and Zingales (1995), Korajczk, Lucas, \& McDonald (1991), Jung, Kim \& Stulz (1996), Welch (2004), Huang \& Ritter (2009), etc. recorded negative relationship between debt equity ratio and market to book ratio which supports the predictions of market timing theory. Complement to these findings, Graham \& Harvey (2001) showed that 67 per cent of the Chief Finance Officers (CFOs) indicated that they time the market when issuing the equity. Similarly, Brav et al (2005) report that 86 per cent of the CFOs said that undervaluation of the stock is the major reason for stock buyback. However, Rajan and Zingales (1995) argued that higher market to book value may also reflect the growth opportunities of the firm in which case one may find positive relationship with debt equity ratio. Chen \& Zhao (2006) also urged that more empirical investigation is required to clearly understand the relationship between leverage and market-to-book value in corporate financing. Our main focus in this study is to find out the link between market value and capital structure. We also include Rajan \& Zingales (2005)'s three control variables, namely, asset tangibility, firm size and profitability, and Fama \& French (2000)'s depreciation as control variables in the leverage regression.

Rajan \& Zingales (1995) argue that higher portion of tangible assets act as collateral which minimizes the agency cost involved in debt financing. Scott (1977), and Myers (1977) contend that large amount of tangible asset may also help the firm to reduce interest cost of debt financing. Therefore, firms with higher tangible assets will have higher debt capacity and it is expected to positively influence the debt equity ratio. Empirically, Titman \& Wessels (1988), Rajan \& Zingales (1995), Espinosa et al (2012), Bhaduri (2002), Khasnobis \& Bhaduri (2002), Bole \& Mahakud (2004), and Mahakud (2006) documented positive relationship between asset tangibility and long-term indebtedness. On the contrary, few studies also found negative relationship between asset tangibility and debt to equity (Hall et al., 2004 and Sogorb-Mira, 2005). Two possible explanations may justify this result; firstly, higher tangible assets may help in reducing information asymmetry problem in the equity market enabling the firm to raise equity capital. Secondly, the firm with large fixed assets may already have generated enough internal capital for financing new projects which reduces its dependency on external capital, particularly, debt capital. However, Berger \& Udell (1994) claimed that asset structure may not be important for a firm which maintains close relationship with lenders which serves as substitute for physical collateral.

Firm size is another important variable which is found to be influencing capital structure. It has been argued that the probability of financial distress may be less in larger firm than small firms (Titman \& Wessels, 1988, Rajan \& Zingales, 1995, and Bhabra, Tong \& Dogan, 2008). In this regard, Warner (1977) showed that the 
bankruptcy cost is the negative function of firm's size. Psillaki \& Daskalakis, (2009) argue that large firms will be in a position to minimize transaction cost and agency cost involved in debt financing. However, Rajan \& Zingales (1995) added that relationship between leverage and size is ambiguous. They argued that there may be inverse relationship between the two as large firms may be able to raise more equity capital due to lesser information asymmetry problem. Empirically, most of the studies documented positive relationship between leverage and size (Barton et al. (1989), Rajan \& Zingales, (1995), Psillaki \& Daskalakis (2009), Espinosa et al (2012), Bole \& Mahakud (2004), Mujumdar (2014), Mohamad (1995) among others). Extant literature also shows that profitability is another major determinant of capital structure. Theoretically, there are divergent views on the role profitability in influencing leverage. According to pecking order hypothesis there is inverse relationship between profitability and leverage as profitable firms will be able generate more internal capital and hence reliance on external capital diminishes (Harris \& Raviv 1991, Rajan \& Zingales 1995, and Booth et al. 2001). On the contrary, trade-off theory postulates opposite prediction. (Jensen and Meckling, 1976, Myers, 1977, and Harris \& Raviv, 1990). Debt financing offers tax advantages to the firms and this is more so in the case highly profitable firms which may induce these firms to go for more debt. On the other hand, creditors will be more willing to lend to a profitable firm. Empirically, several studies recorded negative relationship between leverage and profitability which is in consistent with the prediction of pecking order hypothesis (Harris \& Raviv (1991), Rajan \& Zingales (1995), Booth et al. (2001), Gaud et al. (2005), Ozkan (2001) Van der Wijst and Thurik (1993), and Hall et al. (2004), Strebulaev (2007), and Um (2001)). On the other hand, Espinosa et al (2012) found positive relationship which may support trade off theory.

Besides the above major determinants, we also include depreciation as another control variables. Trade off theory highlights the tax advantages conferred by debt financing, hence there may be positive relationship between tax rate and leverage ratio suggesting that firms facing higher tax rate may be motivated to increase their debt financing. Alternatively, firms can also save tax through depreciation charges. In such case, depreciation acts as non-debt tax shield and hence negative relationship between depreciation and leverage may be expected (Chauhan, 2015). Hence, one would expect negative relationship between depreciation and debt financing.

\subsection{Capital Structure - Some Stylized Facts}

Table 1 presents the composition of stockholders' equity. As evident from the table, reserves and funds are the major component of stockholders equity of which retained earning accounts for about 78 per cent. This shows that internal capital 
continues to be the major source of finance for firms in India. High share of cumulative retained profit may also be due to stock market development and resulting capital gain for the shareholders as investors may be willing to accept lower dividends with higher capital gains. Hence, one could argue that development stock market, on the one hand, will help the firms to raise equity capital from the market, on the other hand it would also help them build internal capital through retained earnings. This will help the firm to reduce the dependence on external finance and the risk associated with external finance, particularly, the debt finance.

Table 1: Composition of Stockholders' Equity

\begin{tabular}{|l|c|c|c|c|c|c|}
\hline & $\mathbf{2 0 1 0 - 1 1}$ & $\mathbf{2 0 1 1 - 1 2}$ & $\mathbf{2 0 1 2 - 1 3}$ & $\mathbf{2 0 1 3 - 1 4}$ & $\mathbf{2 0 1 4 - 1 5}$ & $\mathbf{2 0 1 5 - 1 6}$ \\
\hline & $\%$ & $\%$ & $\%$ & $\%$ & $\%$ & $\%$ \\
\hline Stock holders' Equity & & & & & & \\
\hline Paid up equity capital & 5.16 & 4.79 & 4.64 & 4.36 & 4.19 & 3.99 \\
\hline Paid up preference capital & 0.38 & 0.35 & 0.30 & 0.30 & 0.41 & 0.50 \\
\hline $\begin{array}{l}\text { Capital contribution and } \\
\text { funds by govt, others }\end{array}$ & 0.00 & 0.21 & 0.19 & 0.17 & 0.16 & 0.15 \\
\hline $\begin{array}{l}\text { Money received against } \\
\text { convertible share warrants }\end{array}$ & 0.13 & 0.08 & 0.09 & 0.03 & 0.03 & 0.02 \\
\hline Forfeited equity capital & 0.01 & 0.01 & 0.01 & 0.01 & 0.01 & 0.00 \\
\hline Reserves and funds & 94.09 & 94.48 & 94.68 & 95.11 & 95.03 & 95.26 \\
\hline Of which retained profit & 76.97 & 75.34 & 77.61 & 79.05 & 78.88 & 78.78 \\
\hline $\begin{array}{l}\text { Share application money } \\
\text { \& suspense account }\end{array}$ & 0.23 & 0.08 & 0.10 & 0.03 & 0.19 & 0.07 \\
\hline
\end{tabular}

Source: Compiled from CMIE Prowess Data Base

Table 2 presents the composition of long-term borrowing. It is clear from the table that bank borrowing is the major source of debt for sample firms. The share of long term borrowing from banks has steadily increased over the period of time. This shows that Indian financial system is still a bank dominated one as far as the financing the corporate sector is concerned. Secondly, the table shows that long term capital raised through bonds and debentures accounts for only 15.9 per cent in 2015-16. This demonstrates that the corporate bond market in India is playing limited role in corporate financing. Clearly, there is excessive pressure on the banking sector as far as the corporate financing is concerned. As a result, there is disproportionate risk concentration in one part of the financial system. Concentration of credit and the consequent risk is a serious threat to the financial soundness of the banks with the potential to create systemic crisis, particularly, during the downturn of the business cycle. Unprecedented 
increase in bad loans in Indian Public Sector Banks in the past few years is clear indication of the problem of concentration of risk.

Another important observation from Table 2 is that the share of foreign currency borrowing in the long term borrowing has increased from 17.6 per cent in 2010-11 to 22.30 per cent in 2015-16. An increased foreign currency borrowing is dangerous in the event of large currency depreciation. Patnaik et al. (2016) pointed out that unhedged foreign currency borrowing is a concern in emerging market where exchange rate is not fully floating. They also observed that in an emerging market with managed floating exchange rate regime firms may choose to have unhedged foreign currency borrowing because as firms expect central bank to intervene when faced with large depreciations. However, short term foreign currency borrowing has decreased significantly from 29.31 per cent in 2010-11 to 13.99 in 2015-16 as evident from the Table 3 . This is a welcome trend as high short term foreign currency borrowing may put pressure on the current account thereby widening the deficit.

Table 2: Composition of Long-term Borrowings (in \%)

\begin{tabular}{|l|c|c|c|c|c|c|}
\hline & $\mathbf{2 0 1 0 - 1 1}$ & $\mathbf{2 0 1 1 - 1 2}$ & $\mathbf{2 0 1 2 - 1 3}$ & $\mathbf{2 0 1 3 - 1 4}$ & $\mathbf{2 0 1 4 - 1 5}$ & $\mathbf{2 0 1 5 - 1 6}$ \\
\hline $\begin{array}{l}\text { Long term borrowing from } \\
\text { banks }\end{array}$ & 42.67 & 47.36 & 48.17 & 49.17 & 51.39 & 53.92 \\
\hline $\begin{array}{l}\text { Long term borrowing from } \\
\text { financial institutions }\end{array}$ & 1.51 & 1.30 & 1.44 & 1.30 & 1.19 & 1.45 \\
\hline $\begin{array}{l}\text { Long term borrowings from } \\
\text { central \& state govt }\end{array}$ & 2.22 & 1.86 & 1.31 & 0.98 & 1.00 & 1.10 \\
\hline $\begin{array}{l}\text { Long term borrowings } \\
\text { syndicated across banks \& inst. }\end{array}$ & 0.00 & 0.00 & 0.01 & 0.02 & 0.01 & 0.01 \\
\hline $\begin{array}{l}\text { Long term debentures and } \\
\text { bonds }\end{array}$ & 15.48 & 14.32 & 14.21 & 12.53 & 14.47 & 15.59 \\
\hline $\begin{array}{l}\text { Long term foreign currency } \\
\text { borrowings }\end{array}$ & 17.46 & 22.86 & 21.98 & 24.42 & 22.70 & 22.30 \\
\hline $\begin{array}{l}\text { Long term loans from } \\
\text { promoters, directors and } \\
\text { shareholders }\end{array}$ & 0.04 & 0.03 & 0.04 & 0.06 & 0.07 & 0.07 \\
\hline Long term inter-corporate loans & 0.87 & 1.87 & 1.81 & 1.87 & 1.80 & 1.64 \\
\hline Long term deferred credit & 1.89 & 2.18 & 1.64 & 1.18 & 1.05 & 1.04 \\
\hline $\begin{array}{l}\text { Long term maturities of finance } \\
\text { lease obligations }\end{array}$ & 0.15 & 0.15 & 0.12 & 0.66 & 0.70 & 0.71 \\
\hline Long term fixed deposits & 1.17 & 1.08 & 0.93 & 0.76 & 0.35 & 0.19 \\
\hline Other long term borrowings & 1.95 & 1.73 & 1.43 & 1.18 & 1.09 & 1.12 \\
\hline $\begin{array}{l}\text { Current portion of long term } \\
\text { borrowings }\end{array}$ & 13.15 & 18.93 & 15.49 & 12.95 & 13.22 & 16.95 \\
\hline $\begin{array}{l}\text { Interest accrued and due (long } \\
\text { term) on borrowings }\end{array}$ & 0.01 & 0.03 & 0.01 & 0.01 & 0.01 & 0.01 \\
\hline
\end{tabular}

Source: Compiled from CMIE Prowess Data Base 
154 | MUDRA: Journal of Finance and Accounting, Volume 4, Issue 2, Jul-Dec 2017

Table 3: Composition of Short-term Borrowings (in \%)

\begin{tabular}{|l|c|c|c|c|c|c|}
\hline & $\mathbf{2 0 1 0 - 1 1}$ & $\mathbf{2 0 1 1 - 1 2}$ & $\mathbf{2 0 1 2 - 1 3}$ & $\mathbf{2 0 1 3 - 1 4}$ & $\mathbf{2 0 1 4 - 1 5}$ & $\mathbf{2 0 1 5 - 1 6}$ \\
\hline Short-term borrowing from banks & 60.14 & 52.74 & 53.62 & 62.028 & 66.39 & 63.50 \\
\hline $\begin{array}{l}\text { Short term borrowing from } \\
\text { financial institutions }\end{array}$ & 0.16 & 0.20 & 0.11 & 0.184 & 0.36 & 0.25 \\
\hline $\begin{array}{l}\text { Short term borrowings from } \\
\text { central \& state govt }\end{array}$ & 0.00 & 0.00 & 0.00 & 0.000 & 0.00 & 0.00 \\
\hline $\begin{array}{l}\text { Short term borrowings syndicated } \\
\text { across banks \& institutions }\end{array}$ & 0.00 & 0.00 & 0.00 & 0.006 & 0.01 & 0.01 \\
\hline Short term debentures and bonds & 0.37 & 0.07 & 0.01 & 0.000 & 0.17 & 0.00 \\
\hline $\begin{array}{l}\text { Short term foreign currency } \\
\text { borrowings }\end{array}$ & 29.31 & 31.70 & 32.59 & 24.585 & 15.53 & 13.99 \\
\hline $\begin{array}{l}\text { Short term loans from promoters, } \\
\text { directors and shareholders }\end{array}$ & 0.06 & 0.06 & 0.06 & 0.095 & 0.08 & 0.11 \\
\hline Short term inter-corporate loans & 2.91 & 3.28 & 2.41 & 1.833 & 2.87 & 3.11 \\
\hline Short term deferred credit & 2.37 & 5.74 & 5.63 & 5.533 & 6.40 & 6.83 \\
\hline Short term fixed deposits & 0.15 & 0.13 & 0.13 & 0.091 & 0.07 & 0.09 \\
\hline Short term commercial papers & 2.68 & 4.67 & 4.29 & 4.245 & 6.26 & 10.36 \\
\hline Other short term borrowings & 1.85 & 1.42 & 1.14 & 1.401 & 1.86 & 1.77 \\
\hline $\begin{array}{l}\text { Interest accrued and due on } \\
\text { borrowings }\end{array}$ & 0.31 & 0.39 & 0.47 & 0.641 & 1.32 & 2.50 \\
\hline
\end{tabular}

Source: Compiled from CMIE Prowess Data Base.

Another important feature of corporate debt is the dominance of secured borrowing which has steadily increased over the period as evident from Table 4 . This implies that asset based lending approach dominates in banks and financial institutions. In this regard, Reddy (2004) questioned the practice of asset based lending, particularly, in an era where technology and other intangible assets are more important than material components of the firm.

Table 4: Secured and Unsecured Borrowings

\begin{tabular}{|l|c|c|c|c|c|c|}
\hline & $\mathbf{2 0 1 0 - 1 1}$ & $\mathbf{2 0 1 1 - 1 2}$ & $\mathbf{2 0 1 2 - 1 3}$ & $\mathbf{2 0 1 3 - 1 4}$ & $\mathbf{2 0 1 4 - 1 5}$ & $\mathbf{2 0 1 5 - 1 6}$ \\
\hline & $\mathbf{\%}$ & $\mathbf{\%}$ & $\mathbf{\%}$ & $\mathbf{\%}$ & $\mathbf{\%}$ & \% \\
\hline Secured Borrowings & 57.72 & 56.33 & 60.37 & 63.50 & 65.75 & 65.78 \\
\hline Unsecured Borrowings & 42.28 & 55.86 & 39.63 & 36.50 & 34.25 & 34.22 \\
\hline Secured long run & 60.26 & 61.16 & 62.49 & 62.07 & 65.63 & 64.56 \\
\hline Secured short run & 39.74 & 38.84 & 37.51 & 37.93 & 34.37 & 35.44 \\
\hline Unsecured long run & 46.19 & 45.18 & 45.57 & 55.87 & 68.76 & 69.90 \\
\hline Unsecured short run & 53.81 & 54.82 & 54.43 & 44.13 & 31.24 & 30.10 \\
\hline
\end{tabular}

Source: Compiled from CMIE Prowess Data Base 
This is more so in the case of service sector where intangible components such as technology, software, human capital, brand, and so on are more valuable than tangible assets. One argument for collateral based lending is that it reduces the problem of NPAs. But as argued by Reddy (2004), in micro-finance, with no collaterals and high interest rates, the level of NPAs is very low ${ }^{1}$. Clearly, there is a need for income based lending where the lending is based on a firm's ability to generate income rather than stock of collateral assets.

Table 5 presents the frequency of firms in terms of debt equity ratio. About 64 per cent of the firms are sound in terms of leverage. Around five per cent of the firms are overleveraged with debt equity ratio more than 5 . Though there are few firms with high debt equity ratio, their share in total debt is very high. For example, top twenty highly indebted firms accounted for 63.18 per cent of the total bank borrowings of the sample firms in 2015-16 (Table 7). This concentration of credit and the resulting concentration of NPA is major problem in India Banking Sector, particularly, among the public sector banks. For example, The Hindu (2016) reported that the amount of top twenty NPA accounts of PSBs stood at Rs. 1.54 lakh crores as of June 2016 which is about 28.52 per cent of the total NPAs of PSBs in FY2016. State bank of India, the largest bank in India, had NPA concentration ratio ${ }^{2}$ of 27.36 per cent in FY2016.

Table 5: Distribution of Firms in terms of Debt Equity Ratio

\begin{tabular}{|l|c|c|c|c|c|c|c|}
\hline $\begin{array}{c}\text { Debt equity ratio } \\
\text { (times) }\end{array}$ & $\mathbf{2 0 0 9 - 1 0}$ & $\mathbf{2 0 1 0 - 1 1}$ & $\mathbf{2 0 1 1 - 1 2}$ & $\mathbf{2 0 1 2 - 1 3}$ & $\mathbf{2 0 1 3 - 1 4}$ & $\mathbf{2 0 1 4 - 1 5}$ & $\mathbf{2 0 1 5 - 1 6}$ \\
\hline $\begin{array}{l}\text { Equal or less than } \\
\text { one }\end{array}$ & $\begin{array}{c}1035 \\
(63)\end{array}$ & $\begin{array}{c}1047 \\
(62.77)\end{array}$ & $\begin{array}{c}1036 \\
(61.7)\end{array}$ & $\begin{array}{c}1022 \\
(60.65)\end{array}$ & $\begin{array}{c}1026 \\
(60.78)\end{array}$ & $\begin{array}{c}1044 \\
(62.62)\end{array}$ & $\begin{array}{c}1051 \\
(64.39)\end{array}$ \\
\hline $\begin{array}{l}\text { More than one less } \\
\text { or equal to 5 }\end{array}$ & $\begin{array}{c}565 \\
(34)\end{array}$ & $\begin{array}{c}569 \\
(34.11)\end{array}$ & $\begin{array}{c}582 \\
(34.66)\end{array}$ & $\begin{array}{c}607 \\
(36.02)\end{array}$ & $\begin{array}{c}591 \\
(35.01)\end{array}$ & $\begin{array}{c}552 \\
(33.11)\end{array}$ & $\begin{array}{c}499 \\
(30.57)\end{array}$ \\
\hline $\begin{array}{l}\text { More than 5 less or } \\
\text { equal to 10 }\end{array}$ & 36 & 28 & $\begin{array}{c}33 \\
(1.96)\end{array}$ & $\begin{array}{c}36 \\
(2.14)\end{array}$ & $\begin{array}{c}47 \\
(2.78)\end{array}$ & $\begin{array}{c}43 \\
(2.57)\end{array}$ & $\begin{array}{c}38 \\
(2.32)\end{array}$ \\
\hline More than 10 & 19 & $\begin{array}{c}24 \\
(1.44)\end{array}$ & $\begin{array}{c}28 \\
(1.66)\end{array}$ & $\begin{array}{c}20 \\
(1.19)\end{array}$ & $\begin{array}{c}24 \\
(1.42)\end{array}$ & $\begin{array}{c}28 \\
(1.67)\end{array}$ & $\begin{array}{c}44 \\
(2.69)\end{array}$ \\
\hline
\end{tabular}

Source: Compiled from CMIE Prowess Data Base. Percentage in bracket.

RBI (2017) also found that large borrowers account for 56 per cent of gross advances and 86.5 per cent of GNPAs of SCBs in India. Table 6 presents the percentage distribution of firms in terms interest coverage ratio. As evident from the table, the position has worsened over the period of time as the percentage of firms in distress has increased from about 13 per cent in 2009-10 to 21.10 per cent in 2015-16. Another 10 
per of the firms have ICR in the range 0 to 1 which again indicates that they are very vulnerable. Further, 105 firms with negative ICR accounted for about 30 per cent of the total bank barrowings of the sample firms in 2015-16.

Table 6: Distribution of Firms in terms of Interest Coverage Ratio

\begin{tabular}{|l|c|c|c|c|c|c|c|}
\hline & $\mathbf{2 0 0 9 - 1 0}$ & $\mathbf{2 0 1 0 - 1 1}$ & $\mathbf{2 0 1 1 - 1 2}$ & $\mathbf{2 0 1 2 - 1 3}$ & $\mathbf{2 0 1 3 - 1 4}$ & $\mathbf{2 0 1 4 - 1 5}$ & $\mathbf{2 0 1 5 - 1 6}$ \\
\hline Less than 0 & 234 & 214 & 316 & 321 & 354 & 382 & 364 \\
& $(12.97)$ & $(11.73)$ & $(17.27)$ & $(17.64)$ & $(19.50)$ & $(21.50)$ & $(21.10)$ \\
\hline More than 0 less & 118 & 116 & 182 & 181 & 200 & 195 & 173 \\
than or equal to 1 & $(6.54)$ & $(6.36)$ & $(9.95)$ & $(9.95)$ & $(11.01)$ & $(10.97)$ & $(10.02)$ \\
\hline More than 1 less & 927 & 949 & 898 & 918 & 858 & 768 & 717 \\
than or equal to 5 & $(51.38)$ & $(52.05)$ & $(49.09)$ & $(50.46)$ & $(47.27)$ & $(43.24)$ & $(41.56)$ \\
\hline More than 5 less & 196 & 196 & 140 & 131 & 123 & 145 & 149 \\
than or equal to 10 & $(10.86)$ & $(10.75)$ & $(7.65)$ & $(7.20)$ & $(6.77)$ & $(8.16)$ & $(8.63)$ \\
\hline More than 10 & 329 & 348 & 293 & 268 & 280 & 286 & 322 \\
& $(18.23)$ & $(19.08)$ & $(16.01)$ & $(14.73)$ & $(15.42)$ & $(16.10)$ & $(18.66)$ \\
\hline
\end{tabular}

Source: Compiled from CMIE Prowess Database.

Note: Percentage in bracket.

Table 7 shows the position of top twenty indebted firms which accounted for 63.18 per cent of the total bank borrowings of the sample firms in 2015-16. Majority of the firms reported negative profit, negative return on assets, lower current ratio and interest cover ratio, and higher debt equity ratio which clearly points out the vulnerability of these firms. This has ramification for the banking sector in terms of rising bad debts given the fact that borrowing from the banks constitutes about 60 per cent of the total corporate debt as shown in table 2 and 3. Clearly, it appears that corporate distress is one of the major reasons behind the increasing problem of bad loans in banking sector.

\subsection{Data Sources and Methodology}

The study aims at examining the role of firm's market value on its capital structure decisions in the case of public limited manufacturing firms in India. To do this, our sample consists of firms for which we could get the Date of First Trading (DFT) on BSE or NSE. CMIE Prowess gives the date of first trading in stock exchange and not IPO date. Therefore, we use first trading date instead of IPO as we could not identify the IPO date for all the firms. Studying firms from DFT helps us to understand the evolution of leverage from a given starting point, that is, DFT. We get the sample firms with DFT from 1995 through 2015. We do not go before 1995 as stock market was largely 
underdeveloped. We further stop at March 2015 in order to get at least one year of data after DFT. We study the firms in 3 sub samples DFT +1 year, DFT +5 year, and DFT +10 year to understand both short term and long term impact market value on equity issues. The sample size is 605,490 , and 317 firms for DFT +1 , DFT +5 , and DFT +10 respectively. Sample size decreased as we took longer years either due to exit of the firms or due to non-availability complete data.

Table 7: Top 20 Indebted firms (as on March 2016)

\begin{tabular}{|l|c|c|c|c|c|c|}
\hline \multicolumn{1}{|c|}{ Company Name } & $\begin{array}{c}\text { Profit } \\
\text { after tax } \\
\text { (crore) }\end{array}$ & $\begin{array}{c}\text { Return } \\
\text { on Assets } \\
(\boldsymbol{\%})\end{array}$ & $\begin{array}{c}\text { Curren } \\
\text { t ratio } \\
\text { (times) }\end{array}$ & $\begin{array}{c}\text { Debt to } \\
\text { equity } \\
\text { ratio } \\
\text { (times) }\end{array}$ & $\begin{array}{c}\text { Interes } \\
\text { t cover } \\
\text { (times) }\end{array}$ & $\begin{array}{c}\text { Total Bank } \\
\text { Borrowings } \\
\text { (Crores) }\end{array}$ \\
\hline Reliance Industries Ltd. & 27384 & 6.23 & 0.66 & 0.42 & 10.53 & 67341 \\
\hline Bhushan Steel Ltd. & -2839.37 & -5.3 & 0.77 & 9.92 & -0.23 & 32555.68 \\
\hline Videocon Industries Ltd. & -55.81 & -0.15 & 2.01 & 2.31 & 0.97 & 22304.06 \\
\hline Jaiprakash Associates Ltd. & -3239.9 & -5.75 & 0.85 & 2 & -0.02 & 21841.25 \\
\hline Jindal Steel \& Power Ltd. & -1018.88 & -2.29 & 0.46 & 2.27 & 0.38 & 18299.99 \\
\hline Hindalco Industries Ltd. & 607.25 & 0.52 & 1.95 & 0.78 & 1.23 & 17644.1 \\
\hline Alok Industries Ltd. & -3722.8 & -12.84 & 1.17 & 12.7 & -1.21 & 16081.2 \\
\hline Vedanta Ltd. & 5472.79 & 6.35 & 0.57 & 1.11 & 2.63 & 15889.84 \\
\hline J S W Steel Ltd. & -3529.67 & -5.08 & 0.51 & 1.82 & -0.68 & 10315.94 \\
\hline Electrosteel Steels Ltd. & -326.55 & -2.55 & 0.24 & 23.27 & 0.7 & 9082.16 \\
\hline Bajaj Hindusthan Sugar Ltd. & -114.28 & -0.91 & 1.1 & 3 & 0.86 & 6812.19 \\
\hline Bombay Rayon Fashions Ltd. & 48.85 & 0.36 & 1.24 & 2.06 & 1.06 & 5355.27 \\
\hline Jyoti Structures Ltd. & -503.34 & -9.04 & 0.94 & 50.46 & 0.09 & 4760.6 \\
\hline Century Textiles \& Inds. Ltd. & -54.52 & -1.1 & 0.61 & 2.63 & 0.77 & 4414.57 \\
\hline National Fertilizers Ltd. & 197.09 & 1.12 & 1.15 & 1.28 & 1.52 & 4177.23 \\
\hline Jayaswal Neco Inds. Ltd. & -86.54 & -0.86 & 0.74 & 1.96 & 0.89 & 3867.47 \\
\hline United Spirits Ltd. & 981.16 & 5.22 & 0.91 & 1.5 & 2.47 & 3719.14 \\
\hline Kesoram Industries Ltd. & 137.12 & -8.8 & 1.1 & 16.81 & 0.07 & 3682.21 \\
\hline Piramal Enterprises Ltd. & 1061.15 & 3.82 & 0.36 & 1.1 & 2.29 & 2870.05 \\
\hline Metalyst Forgings Ltd. & -270.21 & -1.1 & 0.72 & 3.49 & 0.27 & 2768.95 \\
\hline Sorrce Compiled from CMIE Prover| & & & & & \\
\hline
\end{tabular}

Source: Compiled from CMIE Prowess Database

The study employs panel data technique for the analysis for DFT +5 and DFT +10 analysis and cross section regression for DFT+1 analysis. In order to overcome the problem of heteroskedasticity and autocorrelation, we used heteroskedasticity and autocorrelation corrected (robust) standard errors. The model is specified as follows;

$$
\begin{aligned}
\left(\frac{D}{A}\right)_{t}-\left(\frac{D}{A}\right)_{t-1} & =a+b\left(\frac{M}{B}\right)_{t-1}+c\left(\frac{F A}{A}\right)_{t-1}+d\left(\frac{\text { EBITDA }}{A}\right)_{t-1}+e\left(\frac{D i v}{A}\right)_{t-1} \\
& +f \log (S)_{t-1}+g\left(\frac{D}{F A}\right)_{t-1}+\mu_{t}
\end{aligned}
$$


Description of these variables is provided in Table 8. All the dependent variables are lagged by one year as changes in leverage in response to these variables may happen in lags. This also overcomes the problem of reverse causality which may exist between dependent and independent variables.

Table 8: Description of Variables

\begin{tabular}{|c|l|c|c|}
\hline S.No & \multicolumn{1}{|c|}{ Variables } & Definition & Notation in (1) \\
\hline 1. & Change in Debt ratio & Change in ratio of total debt to total assets & $\left(\frac{\mathrm{D}}{\mathrm{A}}\right)_{\mathrm{t}}-\left(\frac{\mathrm{D}}{\mathrm{A}}\right)_{\mathrm{t}-1}$ \\
\hline 2. & Market- to- book ratio & $\begin{array}{c}\text { Market capitalization plus book assets } \\
\text { minus book equity all divided by total assets }\end{array}$ & $\left(\frac{\mathrm{M}}{\mathrm{B}}\right)$ \\
\hline 3. & Asset tangibility & Ratio of fixed assets (FA) to total assets & $\left(\frac{\mathrm{FA}}{\mathrm{A}}\right)$ \\
\hline 4. & Logsales & Logarithm of sales turnover & $\log (\mathrm{S})$ \\
\hline 5. & Profitability & Ratio of operating profit to total assets & $\left(\frac{\mathrm{EBITDA}}{\mathrm{A}}\right)$ \\
\hline 6 & Depreciation & Ratio of total depreciation (D) to fixed \\
assets & $\left(\frac{\mathrm{D}}{\mathrm{FA}}\right)$ \\
\hline
\end{tabular}

\subsection{Findings and Discussions}

Extant literature shows that firms' capital structure is influenced by two factors namely a) internal factors and b) market valuation. Variables such as firm size, asset tangibility, profitability and depreciation have been used to control the impact of internal variables on capital structure. Market to book ratio used to explain the role of market valuation on capital structure. Table 9 presents the estimated results of regression (1).

As evident from Table 9, market to book ratio is found to be negatively influencing the debt ratio in all three sub samples. This indicates that firms' debt ratio decreases as market value of the firms' increases suggesting that firms prefer to issue equity when the market value is high. Our results also suggest that the impact of market valuation remains even after ten year from the date of first trading in the stock market. This indicates that market valuation has long term impact on the capital structure. This is contrary to the predictions of trade off theory that market value results in only short term deviation from the optimum capital structure and quickly reverse to the target rate. Therefore, our results are consistent with the predictions of market timing theory that firms with better market value may prefer equity to borrowing, and that the market value has persistent impact on the capital structure. Alternatively, negative relationship of market value with leverage would also support the arguments of Myers (1977), Rajan 
and Zingales (1995), and Frank and Goyal (2009) that firm with higher growth opportunities would use more equity finance. Since, market value reflects the future growth opportunities of the firm, higher market value would induce the firm to use more equity finance.

Table 9: Results of Panel Data

\begin{tabular}{|l|c|c|c|}
\hline $\begin{array}{c}\text { Dependent Variable: } \\
\text { Change in debt ratio }\end{array}$ & DFT +1 & DFT+5 & DFT+10 \\
\hline Market to book value & -0.0063 & -0.00086 & -01122 \\
& $\left(-2.50^{*}\right)$ & $\left(-2.16^{* *}\right)$ & $\left(-1.63^{* * *)}\right.$ \\
\hline Asset tangibility & 0.480 & 0.0294 & 0.0877 \\
& $\left(2.54^{*}\right)$ & $(0.81)$ & $\left(3.49^{*}\right)$ \\
\hline Size & -1.501 & -1.6782 & -1.154 \\
& $\left(-7.27^{*}\right)$ & $(3.69 *)$ & $\left(3.41^{*}\right)$ \\
\hline ROA & 0.126 & -0.1305 & -0.209 \\
& $\left(2.03^{* *}\right)$ & $(-0.99)$ & $(-3.05 *)$ \\
\hline Depreciation & -0.1726 & 0.0786 & 0.0786 \\
& $(-0.72)$ & $(0.58)$ & $(0.58)$ \\
\hline F test & 20.44 & 18.39 & 8.15 \\
& $(0.000)$ & $(0.000)$ & $(0.000)$ \\
\hline
\end{tabular}

Note: $t$ values in parentheses.

*Significant at 1\%. ** Significant at 5\%.*** Significant at 10\%

With regard to the impact of asset tangibility on borrowing of the firms, we found positive significant influence of asset tangibility on long term debt ratio indicating that higher proportion of tangible assets increases the debt capacity of the firm as lenders will be willing to lend to a firm with higher tangible asserts. (Rajan\& Zingales, 1995). Alternatively, positive influence of tangible assets also supports the proposition that higher tangible asset helps in reducing information asymmetry problem associated with debt financing which may help the firm to minimize the interest costs of the debt as argued by Scott (1977), and Myers (1977). However, firm size is found to be negatively related with debt ratio. This suggests that large firms have lower debt indicating that they raise more equity capital to finance their operation. This may be due to the fact that in India before 1990s firms were constrained to depend more on debt capital as the stock market was largely underdeveloped. Therefore, as stock market became more efficient, firms, particularly, large firms took advantage of it and raised more equity capital from the market. Alternatively, for a large and growing firm, the problem of information asymmetry reduces and hence they would be able to raise capital from the market at better terms. 
Further, we found significant and negative relationship between profitability and debt ratio in DFT +5 suggesting that profitability firms are able to raise more equity capital from the market. Alternatively, the negative relationship may also reflect the dependence on internal capital which is consistent with predictions of pecking order hypothesis. But, in the long run $(\mathrm{DFT}+10)$ profitability is positively affecting the debt capacity of the firm which suggests that as firms expands their profitability helps them to raise more debt. However, we did not find any significant relationship between depreciation and debt ratio which suggests that tax based explanations are not relevant in the case of our sample firms.

Results of regression (1) indicate that firm's market value negatively influences the long run debt ratio. However, negative relationship between market value and debt ratio may also be due to higher retained earnings or lower debt. In order to ascertain that negative relationship is actually due to changes in equity issues, we further examined relationship between fresh equity issues and market value of the firm. We study the firms in 3 sub samples DFT $+1, \mathrm{DFT}+5$ and DFT +10 to understand both short term and long term impact market value on equity issues. Our regression model is as follows:

$$
\left(\frac{\mathrm{e}}{\mathrm{A}}\right)_{t}=\mathrm{a}+\mathrm{b}\left(\frac{\mathrm{M}}{\mathrm{B}}\right)_{\mathrm{t}-1}+\mathrm{c}\left(\frac{\mathrm{FA}}{\mathrm{A}}\right)_{\mathrm{t}-1}+\mathrm{d}\left(\frac{\text { EBITDA }}{\mathrm{A}}\right)_{\mathrm{t}-1}+\mathrm{e}\left(\frac{\text { Div }}{\mathrm{A}}\right)_{\mathrm{t}-1}+\mathrm{f} \log (\mathrm{S})_{\mathrm{t}-1}+\mu_{\mathrm{t}}
$$

where, $\left(\frac{\mathrm{e}}{\mathrm{A}}\right)_{\mathrm{t}}$ is the ratio of fresh equity issue to total assets.

Estimated results of regression (2) are presented in Table 10.

Table 10: Results of Regression (2)

\begin{tabular}{|l|c|c|c|}
\hline $\begin{array}{c}\text { Dependent Variable: } \\
\text { Fresh equity issues }\end{array}$ & DFT+1 & DFT +5 & DFT +10 \\
\hline Market to book value & 0.0017 & 0.00151 & 7.08 \\
& $\left(2.77^{*}\right)$ & $\left(2.14^{*}\right)$ & $\left(3.83^{*}\right)$ \\
\hline Asset tangibility & -0.020 & -0.00061 & -0.00092 \\
& $(-1.26)$ & $(-3.57 *)$ & $\left(-2.03^{* *}\right)$ \\
\hline Size & -0.709 & -0.0065 & -0.00058 \\
& $\left(-2.86^{*}\right)$ & $(-3.09 *)$ & $\left(-2.05^{* *}\right)$ \\
\hline Profitability & 0.018 & -0.00048 & 0.00061 \\
& $(0.66)$ & $(-2.30 * *)$ & $\left(2.92^{*}\right)$ \\
\hline Depreciation & -0.023 & -2.01 & -0.00002 \\
& $(-0.76)$ & $(-0.99)$ & $(-0.07)$ \\
\hline F test & 4.18 & 9.88 & 108.39 \\
& $(0.060)$ & $(0.000)$ & $(0.000)$ \\
\hline
\end{tabular}

Note: $t$ values in parentheses.

*Significant at 1\%.** Significant at 5\%.*** Significant at 10\% 
As shown in Table 10, market value is positively and significantly related with equity issue. This shows that higher market value leads lower debt ratio through increase in equity issues which confirms that negative impact of market value on debt ratio is indeed traced to changes in equity issues than changes in retained earnings or debt retirement. Further, the impact of market value on equity issues is more pronounced in DFT +10 which indicates the impact of market value on capital structure is persistent as opposed to the argument of trade off theory that market value should have only short impact on capital structure. This shows that market value of the firm leads to long term change in firms' capital structure which is consistent with the market timing theory of Baker and Wurgler (2002).

\subsection{Conclusion}

In this study, we attempted to examine the impact of firm's market value on capital structure. We used market to book ratio as the measure of market value of the firm and debt ratio as the measure of capital structure. Our results show that long run debt ratio is negatively influenced by market value. Further, we showed that the negative relationship actually comes through equity issue and the impact remains even after ten years from the date of first trading in equity market. This is consistent with the predictions of market timing theory that the market value has long term impact on firm's capital structure. Our results suggests that better market valuation enables the firm to raise capital from equity market thereby diffusing excessive burden on banking system by sharing the risk of financing corporate sector. Stock market also helps to disseminate information about the growth prospects of the firms which would help firms to borrow at better terms.

\section{Endnotes}

1. For example, Bangalore based leading microfinance institute Ujjivan Financial Services Pvt. Ltd reported Gross NPA rate of just 0.28 per cent in FY 2016-17 as against 13.37 per cent in Public Sector Banks.

2. Share of top four NPA accounts.

\section{References}

Ali, A., H.J., \& Hisham, N. (2009). Revisiting capital structure theory: a test of pecking order and static trade-off model from Malaysian capital market. International Research Journal of Finance and Economics, 30, 58-65. 
162 | MUDRA: Journal of Finance and Accounting, Volume 4, Issue 2, Jul-Dec 2017

Alti, A. (2006). How persistent is the impact of market timing on capital structure? The Journal of Finance, 51(4), 1681-1710.

Baker, M. \& Jeffrey, W. (2002). Market timing and capital structure. The Journal of Finance, 57(1), 1-32.

Barton, S. L., Ned, C. H. \& Srinivasan, S. (1989). An empirical test of stakeholder theory predictions of capital structure. Financial Management, 18(1), 36-44.

Baxter, N. D. (1967). Leverage, the risk of ruin and the cost of capital. Journal of Finance, 22(3), 395-403.

Berger, A. N., \& Udell, Gregory F. (2005). A more complete conceptual framework for financing of small and medium enterprises. World Bank Policy Research Working Paper 3795, December 2005.

Bhabra, H. S., Tong, L. \& Dogan, T. (2008). Capital structure choice in a nascent market: Evidence from listed firms in China. Financial Management, 37(2), 341-364.

Bhaduri, S. N. (2002a). Determinants of corporate borrowing: some evidence from the Indian corporate sector. Journal of Econ Finance, 26(2), 200-215.

Bhaduri, S. N. (2002b). Determinants of capital structure choice: a study of Indian corporate sector. Applied Financial Economics, 12(9), 655-665.

Brav, A., Graham, J., Harvey, C. \& Michaely, R. (2005). Payout policy in the 21st century. Journal of Financial Economics, 77(3), 483-527.

Bole, LM, \& Mahakud, J. (2004). Trends and determinants of capital structure in India: A panel data analysis. Finance India, 18(1), 37-55.

Booth, L., Aivazian, V., Demirguc-Kunt, A., \& Maksimovic, V. (2001). Capital structure in developing countries. Journal of Finance, 56(1), 87-130.

Chauhan, G. S. (2015). Capital structure in India: implications for the development of bond markets. Indian Journal of Economics \& Business, 14(2), 245-267. 
Daskalakis, N., \& Psillaki, M. (2008). Do country or firm factors explain capital structure? Evidence from SMEs in France and Greece. Applied Financial Economics, 18(1), 87-97.

DeAngelo, H. \& Ronald, M. (1980). Optimal capital structure under corporate and personal taxation. Journal of Financial Economics, 8(1), 3-29.

Demirgüç-Kunt, A. \& Vojislav, M. (1996). Stock market development and financing choices of firms. The World Bank Economic Review, 10(2), 341-369.

Espinosa, C. M., Carlos M. V., Vieito, J. P. \& Marcelo, G. A. (2012) Capital structures in developing countries: The Latin American case. Investigation Economica, 71(282), $35-54$.

Fama E, \& French K (2002) Testing trade-off and pecking order predictions about dividends and debt. Review of Financial Studies, 15(1), 1-33.

Frank M.Z., \& Goyal V.K. (2003). Testing the pecking order theory of capital structure. Journal of Financial Economics, 67(2), 217-248.

Frank, M.Z., \& Goyal, V.K. (2009). Capital structure decisions: Which factors are reliably important? Financial Management, 38(1), 1-37.

Gaud, P., Jani, E., Hoesli, M., \& Bender, A. (2005). The capital structure of Swiss companies: An empirical analysis using dynamic panel data. European Financial Management, 77(1), 51-69.

Graham, J.R. \& Harvey, C.R. (2001). The theory and practice of corporate finance: evidence from the field. Journal of Financial Economics, 60(2-3), 187-243.

Hall, G., Hutchinson, P., \& Michaelas, N. (2004). Determinants of the capital structure of European SMEs. Journal of Business Finance and Accounting, 31(5), 711-728.

Harris, M., \& Raviv, A. (1990). Capital structure and the informational role of debt. The Journal of Finance, 45(2), 321-349. 
Harris, M., \& Raviv, A. (1991).The theory of capital structure. The Journal of Finance, 46(1), 297-355.

Huang, R. \& Jay, R. R. (2009). Testing theories of capital structure and estimating the speed of adjustment. The Journal of Financial and Quantitative Analysis, 44(2), 237271.

Hovakimian, A., Opler, T. \& S. Titman (2001). The debt-equity choice. Journal of Financial and Quantitative Analysis, 36(1), 1-24.

Jalal, A. I. M. (2007.) The pecking order, information asymmetry, and financial market efficiency, Doctoral Dissertation, The University of Minnesota.

Jensen, M. \& Meckling, N. (1976). The theory of the firm: Managerial behavior agency cost and ownership structure. Journal of Financial Economics, 3(4), 305 - 360.

Jung, K., Kim, Y., \& Stulz, R. (1996) Timing, investment opportunities, managerial discretion, and the security issue decision. Journal of Financial Economics, 42(2), 159185 .

Khasnobis, B. G., \& Saumitra, N. B. (2002). Determinants of capital structure in India (1990-1998): A dynamic panel data approach. Journal of Economic Integration, 17 (4), 761-776.

Korajczyk, R., Deborah, L., \& McDonald, R. (1991). The effects of information releases on the pricing and timing of equity issues. Review of Financial Studies, 4(4), 685-708.

Mahakud, J. (2006). Testing the pecking order theory of capital structure: evidence from Indian corporate sector. ICFAI J Applied Finance, 12(11), 16-26.

Miller, M. H. (1977). Debt and taxes source. The Journal of Finance, 32(2), 261-275.

Mujumdar, R. (2014). Indebtedness in the small and midcap segments: New evidences from Indian manufacturing sector. Management Research Review, 37 (9), 833-854.

Modigliani F, \& Miller M. (1958). The cost of capital, corporate finance and the theory of investment. American Economic Review, 48(3), 261-297. 
Modigliani F., \& Miller M. (1963) Corporate income taxes and the cost of capital. American Economic Review, 53(3), 433-443.

Mohamad, H. M. (1995). Capital structure in large Malaysian companies. Management International Review, 35(2), 119-130.

Myers, S.C. (1977). Determinants of corporate borrowing. Journal of Financial Economics, 9, 147-176.

Myers, S.C. (1984). The capital structure puzzle. The Journal of Finance, 39(3), 575592.

Myers, S.C., \& Majluf, N. (1984). Corporate financing and investment decisions when firms have information that investors do not have. Journal of Financial Economics, 13(2), 187-221.

Patnaik, I., Shaha, A., \& Singh, N. (2016). Foreign currency borrowing by Indian Firms: Towards a new policy framework. Working paper No. 167, National Institute of Public Finance and Policy, New Delhi.

Psillaki, M. \& Nikolaos, D. (2009). Are the determinants of capital structure country or firm specific? Small Business Economics, 33(3), 319-333.

RBI. (2017). Financial Stability Report, No.15. June 2017, Reserve Bank of India, Mumbai.

RBI (2015), Financial Stability Report, June 2015. Reserve Bank of India, Mumbai.

Rajan, R. G., \& Zingales, L. (1995). What do we know about capital structure? Some evidence from international data. Journal of Finance, 50(5), 1421-1459.

Reddy, Y. V. (2004). Credit policy, systems, and culture, Reserve Bank of India Bulletin, March, 2004.

Scott, J. (1977) Bankruptcy, secured debt, and optimal capital structure. Journal of Finance, 32(1), 1-19. 
166 | MUDRA: Journal of Finance and Accounting, Volume 4, Issue 2, Jul-Dec 2017

Sogorb-Mira, F. (2005). How SME uniqueness affects capital structure: Evidence from A 1994-1998 Spanish data panel. Small Business Economics, 25(5), 447-457.

Strebulaev, I. A. (2007). Do tests of capital structure theory mean what they say? The Journal of Finance, 62(4), 1747-1787.

The Hindu (2016, December 2). Details of NPA figures of public, private sector banks.

Titman, S. \& Wessels, R. (1988). The determinants of capital structure choice. Journal of Finance, 43(1), 1-20.

Tong, G., \& Green, C.J. (2005). Pecking order or trade-off hypothesis? Evidence on the capital structure of Chinese companies. Journal of Applied Economics, 37(19), 21792189.

Ozkan, A. (2001). Determinants of capital structure and adjustment to long run target: Evidence from UK company panel data. Journal of Business Finance and Accounting, 28(1\&2),175-199.

Um, T. (2001). Determination of capital structure and prediction of bankruptcy in Korea Doctoral Dissertation, Faculty of the Graduate School, Cornell University, January 2001.

Van der Wijst, D., \& Thurik, R. (1993). Determinants of small firm debt ratios: An analysis of retail panel data. Small Business Economics. 5(1), 55-65.

Warner, J. (1977) Bankruptcy, absolute priority, and the prices of risky debt claims. Journal of Financial Economics, 4, 239-76.

Welch, I. (2004). Capital structure and stock returns. Journal of Political Economy, 112(1), 106-131. 